\title{
Absurdity in Medicine. Stanisław Trzebiński’s Philosophy of Medicine
}

Stanisław Trzebiński (1861-1930), professor at Stefan Batory University in Vilnius, was one of the most distinguished representatives of the Polish School of Philosophy of Medicine before the Second World War. He undertook studies in neurology, philosophy of medicine, and literature.

The article explores Trzebiński's philosophical ideas, especially his call for rationality in medicine and the concept of absurdity in medicine as a precondition for the development of medical knowledge and practice. Today this method is an essential background in Evidence-Based Medicine and confirms cultural and scientific forms of cognition.

Keywords: Stanisław Trzebiński, absurdity, philosophy of medicine

Słowa kluczowe: Stanisław Trzebiński, absurd, filozofia medycyny

\section{Introduction}

In the Structure of Scientific Revolutions, Thomas Kuhn emphasizes the important role of anomalies that are incompatible with the present paradigm in a given field of science. This anomaly is assimilated with actual theory:

Discovery commences with the awareness of an anomaly, i.e., with the recognition that nature has somehow violated the paradigm-induced expectations that govern normal science. It then continues with a more or less extended exploration of the area of anomaly. And it closes only when the paradigm theory has been adjusted so that the anomalous has become the expected. ${ }^{1}$

1 T. Kuhn, The Structure of Scientific Revolutions. Online file: projektintegracija.pravo.hr/_download/repository/ Kuhn_Structure_of_Scientific_Revolutions.pdf [accessed 14.11.2018], p. 52-53. 
Anomaly is, therefore, an inconsistency between empirical observation and theoretical expectation resulting from the valid scientific theory. Recognizing new phenomena is characterized by

the previous awareness of anomaly, the gradual and simultaneous emergence of both observational and conceptual recognition, and the consequent change of paradigm categories and procedures often accompanied by resistance. ${ }^{2}$

In the preface to his work Kuhn draws attention to the research conducted by the Polish microbiologist and philosopher Ludwik Fleck, who dealt with the issue of anomalies in medical sciences. In 1927, Fleck wrote that in the case of medical cognition, what comes into question are the

many elusive for the logics imponderables which allow us to predict and somehow foretell, the course of issues and ideas that determine the development of a given field of thought and create a proper style for the epoch. ${ }^{3}$

Biological factors further complicate formal epistemological difficulties. Some of them were mentioned by Władysław Szumowski, such as a vast number of links in causal chains in living systems, unexplained, mutual alternating of various causal chains, causal chains in living systems do not always lead to success but very often to earlier causes, finally: in biology, it is impossible to repeat the observation or experiment in totally identical conditions. ${ }^{4}$

If we assume that there is no clearly defined line between health and illness, each disease phenomenon is, to some extent, unique; therefore, the scientist's theoretical position should be continuously modified:

And it is so with every medical issue: it constantly and still becomes necessary to change the angle of view, to give way from a consistent mental position. Only thus the world of disease phenomena becomes irrational as a whole and rational in detail. ${ }^{5}$

The way out from absurdity turns out to be abstract thinking and the necessity of abandoning the consequences of adhering to a given traditional scientific explanation. If health and illness are fluctuant in nature, then their analysis cannot conform to constant dogma. In the very moment of cognition, an element of creativity is indispensable for Fleck:

Cognition is neither passive contemplation nor the acquisition of only possible comprehension of what is given as prepared for comprehension. Cognition is an active, vivid relationship-building, reforming and being reformed, shortly - it is creating. ${ }^{6}$

2 Ibid., p. 62.

3 L. Fleck, Genesis and Development of Scientific Fact, Chicago - London 2006, p. 57.

4 W. Szumowski, O związku przyczynowym w medycynie, "Archiwum Historii i Filozofii Medycyny" vol. 2, 1925, no 2, p. 232-237.

5 L. Fleck, Psychosocjologia poznania naukowego, Lublin 2006, p. 171.

6 Ibid., p. 176. 
Kuhn and Fleck were not the first to study the notion of anomalies in the scientific process of cognition. Stanisław Trzebiński was a Polish medical philosopher who had already written about absurdity in medical knowledge in the first half of the 1920s.

\section{Stanisław Trzebiński - a portrayal}

Two opinions characterize the personality of Stanisław Trzebiński (1861-1930) accurately: the first was formulated by Adam Wrzosek who in the 'Archives of the History and Philosophy of Medicine' wrote:

[Trzebiński] was one of the most agreeable people I have ever met in my life. Approaching him, I could feel the charm of his beautiful soul toughened up by many painful blows which easily could have knocked down any other person, leading them to bitterness and losing will to live and work'. ${ }^{7}$

The second view was expressed by Władysław Szumowski, for whom Trzebiński was 'a man with an extraordinarily beautiful character and a mind broad and subtle. He was comparable to Socrates'. ${ }^{8}$ He was modest and full of doubt,

tolerant of all human flaws and faults, sensitive to human poverty, with a strong character, taking all the sore life experiences without complaining. Only when he talked about noble deeds, would he be passionate, with tears in his eyes ${ }^{9}$

- Aleksander Januszkiewicz wrote.

In the philosophical and medical field, Trzebiński was an outstanding persona with numerous publications, mostly gathered in the 'Archives of the History and Philosophy of Medicine' - a journal published in Poland since 1925. In 1922, he became the head of the Department of History and Philosophy of Medicine at Stefan Batory University in Vilnius. ${ }^{10}$ Today, he is ranked among the 'younger' representatives of the Polish school of the philosophy of medicine ${ }^{11}$, which was institutionalized by Władysław Szumowski and, thanks to Adam Wrzosek, popularized in the 'Archives of the History and Philosophy of Medicine'. The School of philosophy and medicine organized regular congresses for philosophers and historians of medicine, and Trzebiński held the fifth one. Szumowski confirms this opinion, emphasizing Trzebiński's role inrecalling Tytus Chałubiński's method of finding medical recommendations.

Ilana Löwy suggests that it is very difficult to univocally state the extent of Trzebiński's influence on the Polish philosophical and medical thought. ${ }^{12}$ Although it is true, we need to consider the political situation in the Second Polish Republic shortly after the procla-

7 A. Wrzosek, Życie i działalność naukowa Stanisława Trzebińskiego, "Archiwum Historii i Filozofii Medycyny" vol. 14, 1934, no 1-2, p. 217.

8 W. Szumowski, Filozofia medycyny, Kęty 2007, p. 63.

9 A. Januszkiewicz, Śp. Prof. Dr. Stanisław Trzebiński. Na podstawie danych biograficznych i własnych wspomnień, "Pamiętnik Wileńskiego Towarzystwa Lekarskiego" vol. 6, 1930, no 4-5, p. III-XI.

10 S. Trzebiński, Wydział lekarski Uniwersytetu Stefana Batorego w latach 1919-1929, Wilno 1931, p. 35.

11 J. Zamojski, Dlaczego wciąż warto badać polską myśl filozoficzno-lekarską?, [in:] Polska szkoła filozofii medycyny, ed. by M. Musielak, J. Zamojski, Poznań 2010, p. 18-19.

12 I. Löwy, The Polish School of Philosophy of Medicine, New York 1990, p. 220-224. 
mation of independence in 1918. The development of the philosophy of medicine was limited indeed, as was every other sphere of social life. The first ten years of independence were spent on organizational work, which hampered any scientific labor - or even made it impossible. ${ }^{13}$ Twenty-one years later, the Second World War put an end to the intellectual and scientific tradition of the epoch, and almost the entire achievement of the Polish school of philosophy of medicine fell into oblivion.

Recreating this continuity today is an arduous task. However, there is progress, mostly because the ideas of Polish doctors-philosophers have been reconstructed and interpreted: generally in a historical and philosophical perspective ${ }^{14}$, by evoking the sources ${ }^{15}$ and leading issues (for instance, the relationship between art and science in medicine) $;{ }^{16}$ in the context of aesthetic studies in medicine; in comparison with other historical concepts in philosophy and medicine; ${ }^{17}$ or by looking for links between the Polish school of philosophy of medicine and other philosophical schools in those times. ${ }^{18}$ We hope that the growing interest in the Polish school of philosophy of medicine should recreate the lost intellectual continuity, especially thanks to the efforts by Michał Musielak and Jan Zamojski, the editors of the Polish School of Philosophy of Medicine, in which one chapter is devoted to Trzebiński. ${ }^{19}$ They are also the co-editors of a Polish-Slovakian volume entitled Polske filosofické myšlení a medicína. ${ }^{20}$

There are very few studies on Stanisław Trzebiński's philosophy. We mention here only one article about the critique of subjectivity, written by Wasilewski, and an extensive and detailed work by Ryszard W. Gryglewski entitled O filozoficznym ujęciu medycyny przez Stanisława Trzebińskiego (On Stanisław Trzebiński's Philosophical Concept of Medicine). ${ }^{21}$ Other than this, there are few attempts to interpret Trzebiński's ideas on the history of medicine or in terms of differences with the claims of neo-romantic German medicine. Because Stanisław Trzebiński's philosophy has not been sufficiently investigated, future studies in this subject should be undertaken. His professional achievements can inspire modern medical knowledge and its methodology not only from the epistemological perspective.

13 S. Trzebiński, $V$ Zjazd Polskich Historyków i Filozofów Medycyny w r. 1929, "Archiwum Historii i Filozofii Medycyny" vol. 11, 1931, no 1-2, p. 14

14 I. Löwy, "Medical Critique" ["Krytyka Lekarska"]: A Journal of Medicine and Philosophy - 1897-1907, "The Journal of Medicine \& Philosophy" vol. 15, 1990, issue 6, p. 653-674.

15 R.W. Gryglewski, Filozofia medycyny Ferdynanda Karola Dworzaczka, "Archiwum Historii i Filozofii Medycyny" vol. 69, 2006, no 1-2, p. 41-46.

16 Idem, Czy medycyna jest sztuką czy nauką? - rozważania w świetle polskiej szkoły filozofii medycyny i poglądów innych lekarzy europejskich czasów przełomu XIX w. do wybuchu II wojny światowej, "Medycyna Nowożytna" vol. 13, 2006, no 1-2, p. 7-24.

17 B. Płonka-Syroka, An Overview of the Polish School of Medical Philosophy from the 19th Century to Today, "Journal of Pharmacy and Pharmacology" 2014, no 2, p. 509-526.

18 Z. Jastrzębowski, T. Srogosz, Polska szkoła filozofii medycyny a marksizm "Medycyna Nowożytna" vol. 1, 1994, no 2, p. 61-68.

19 J. Barański, Stanisław Trzebiński, [in:] Polska szkoła filozofii medycyny. Przedstawiciele $i$ wybrane teksty źródłowe, ed. by M. Musielak, M. Zamojski, Poznań 2010, p. 129-146.

20 Polske filosofické myšlenía medicína, ed. by J. Zamojski, M. Petrů, M. Musielak, L. Vladykova, Ostrava - Košice 2012, p. 35.

21 R. Gryglewski, O filozoficznym ujęciu medycyny przez Stanisława Trzebińskiego, "Forum Bibliotek Medycznych" 2015, no 2, p. 249-260. 


\section{Trzebiński and rational philosophy}

What distinguishes Trzebiński's philosophical and medical reflection on the mind from those of contemporary Polish philosophers of medicine is a consistent rejection of the irrational premises of meditation, characteristic for Romantic and post-Romantic representatives of German philosophers of the epoch (represented by E. Schweninger, G. Honigmann, E. Like, and R. Koch). The representatives of the Polish school of philosophy shared similar views and ideas - a scientific and rational style of philosophical and medical thinking very much in line with Henryk Kramsztyk's 'Medical Critique' and Władysław Matlakowski's 'Medical Journal'. Trzebiński expressed this at the $4^{\text {th }}$ Congress of Historians and Philosophers of Medicine in 1929, arguing with the attempts to introduce irrational elements of thinking into medical practice. He pointed out 'the lack of objective tests and methods in relation to irrational and transcendental factors; therefore, it is doubtful that they may play a role in the field of science'. ${ }^{22}$ This scientific (positivist) model of medicine was so strong in the Polish medical environment that any influence of mesmerism, homeopathy, and intuitionism was consequently rejected. This was emphasized by Trzebiński, who declared his affiliation with rationalism, i.e., this worldview which 'believes that the mental faculty is sufficient to solve these life problems which can be considered solvable without the need of resorting to other irrational faculties of the soul, such as imagination, intuition, inspiration etc. ${ }^{23}$ This does not mean, however, that he ignores the influence of irrational factors in medical treatment. He just admits they do not play a cognitively important role in scientific thinking procedures, despite cases and abbreviated thinking in diagnostics (intuition) and mental suggestion. Referring to Szumowski's allegation that Biegański in The Logic of Medicine (1894) did not address the issue of intuitive cognition, he wrote:

Our knowledge about the irrational and direct elements of cognition is perhaps not too scarce but almost completely unstructured. These are actually just materials the value of which many people passionately oppose. Biegański could only mention that there have always existed and will exist physicians endowed with intuitive skills of identifying illnesses. The proper handbook about logic in medicine should have just only mentioned it. ${ }^{24}$

Some consequences of a univocally negative attitude to irrational aspects of cognition and treatment manifested by the Warsaw medical community were experienced by Julian Ochorowicz, who in the 'Medical Journal' was accused by its editor-in-chief, Władysław Matlakowski, of deception and pseudo-science, the inability to understand the laws of physics, ramblings, and falsehoods brought from Paris. ${ }^{25}$ Many years later (in 1913),

22 T. Bilikiewicz, IV Zjazd polskich historyków i filozofów medycyny, "Archiwum Historii i Filozofii Medycyny" vol. 9, 1929, no 1, p. 41.

23 S. Trzebiński, Racjonalność i racjonalizm w medycynie, "Archiwum Historii i Filozofii Medycyny" vol. 2, 1925, no 1, p. 93.

24 S. Trzebiński, Blane, Oesterlen i Biegański - 3 Logiki medycyny, "Nowiny Lekarskie"vol 38, 1926, no 23, p. 1617.

25 W. Matlakowski, A. Fabian, Dr Filozofii Julian Ochorowicz i nauka. Przyczynek do historii cywilizacji i u nas, "Gazeta Lekarska" vol. 8, 1888, no 23, p. 477-509. 
Trzebiński referred to the medical aspect of suggestion and hypnosis in his article entitled Transcendentalism and Natural Knowledge. ${ }^{26} \mathrm{He}$ does not deny that there is a possibility of psychological influence on the patient, including suggestion and hypnosis, even with therapeutic effects, but he wrote:

Is the mechanism of just described disease symptoms always what Ochorowicz wants? It may be too early to answer this question, but there is no doubt that sometimes it can be so, and this is why there is no reason to refuse it until someone finds a more convincing method. ${ }^{27}$

Therefore, Trzebiński does not reject the credibility of suggestion-related and hypnosis-related therapy; he is rather trying to find a scientific explanation for them. Psychological influence on the patient regulates his vasomotor system so that the reduction of even the largest blood vessels is acceptable here. In the absence of a rational explanation, Trzebiński argues that irrational theory is worth consideration. He wrote: 'What seemed impossible or unusual yesterday today is already a natural thing, and what is still beyond our understanding today may be quite banal tomorrow' ${ }^{28}$

\section{Absurdity in medicine}

Trzebiński's concept of the rationality of medicine is based on considerations regarding the discontinuous development of medical knowledge and medical practice, in which the concept of the absurd is crucial. The absurd is understood as a statement of the deaf person ( $a b$ surdo), which is ridiculously related to the contents of the conversation. In its nonsense, the absurd is a peculiar paradox. About half a century earlier, Ludwik Łętowski called it the idea which is uncommon, bold, and contrary to common explanation:

Every new, first time revealed thought may be called a paradox for as long as it does not obtain citizenship among accepted ideas [...]; and what is a paradox today may not be a paradox tomorrow. ${ }^{29}$

Trzebiński continues with this understanding by distinguishing three meanings of the absurd: first - dialectical, logical mistakes, i.e., bringing judgments to the absurd (absurd per se); the second is the meaning of the apparent absurdity, i.e., the contradiction of the judgments with others that are considered right, widely-accepted and taken for granted: 'in such case a logical mistake may not occur and may not lie in the scope of absurd ${ }^{30}$; the third (as an extension of the second one), colloquially, is the contradiction with common sense. Trzebiński clarifies: 'Everyone thinks that the best of all common senses is their own'. ${ }^{31}$

26 S. Trzebiński, Transcendentalizm a wiedza przyrodnicza i lekarska, "Archiwum Historii i Filozofii Medycyny" vol. 15, 1935, no 2, p. 139-158.

27 Ibid., p. 143.

28 Ibid., p. 71.

29 B. Podgórzanin (L. Łętowski), Miscellanea, vol. 1, Kraków 1866, p. 4.

30 S. Trzebiński, Absurdalność w medycynie, "Archiwum Historii i Filozofii Medycyny" vol. 7, 1927, no 1, p. 73.

31 Ibid. 
For Trzebiński, the apparent absurd is the key. In epistemological cognition, it questions the premises of the theoretical concept which has previously been accepted as true or their conclusion - a therapeutic indication usually based on observation or experiment. An example of such an apparent absurdity which questions the conclusion derived from theoretical premises was the rejection of the medical nature of bloodletting by Józef Dietl. Trzebiński refers here to the ancient concept of plethora, which means 'full-bloodedness' or an 'excess' in the concept of the Greek physician and philosopher, Erasistratos of Keos. He believed that plethora is the result of having an excessive amount of food which, unable to be digested or vomited, enters the blood system. The logical conclusion here is phlebotomy which was used even in case of pneumonia, according to the syllogism:

1. Tuberculosis is an excess of rotten blood.

2. Rotten blood excess is treated with bloodletting.

3. Tuberculosis is treated with bloodletting.

On the basis of these assumptions, Trzebiński explains that Erasistratos' conclusion was perfectly correct. Dietl did not question the premise based on the humoral theory but the conclusion in the form of a therapeutic indication through a clinical experiment: 'Thus, the therapeutic dogma which is the conclusion from the premises once established by Erasistratos is in this case overthrown not because its incorrectness was directly proved, but because our experience has shown the fallacy of the conclusion'. ${ }^{32}$ In the case of protective vaccination, argumentation was very similar:

Having started with observed facts unsupported by any theory, Jenner proposed a method which was accused of absurdity by its opponents, who indicated the danger that would result from the introduction of animal-derived immunization into the human system, and this danger was illustrated with stories in popular brochures about children vaccinated with cow-pox who roared like calves or with the pictures presenting children with cattle heads. ${ }^{33}$

He cites many medical views which were questioned only practically, without discrediting their theoretical justifications. An effective remedy rejected by the then-dominant and widely recognized medical theories relegates them further into the order of dogma:

medical systems have fallen not due to insufficient motivation of their theories but because they did not survive the final test of life practice, sharing their fate with a large number of various other theoretically worse or more justified systems. ${ }^{34}$

Similarly, Ignacy Semmelweis's theories were also considered absurd, as they questioned theoretical premises, i.e., the assumption that the miasma (relatively: body fluids excess, nervous shock, embarrassment, poor diet, milk secretion pressure, emotional disorders, poor oxygenation, subcooling or 'cadaver poison') is the cause of puerperal fever. 
He concluded that this was caused by the animal-organic material being carried on doctors' and students' hands from the autopsy room. Long observation and analysis of data on women's mortality in hospitals allowed Semmelweis to undermine the theoretical and explanatory premises of puerperal fever. Recommendations for handwashing with chlorinated lime were considered absurd by the medical community, who dogmatically held to previous explanations of puerperal fever only because they were justified in the humoral theory or in the prevailing visions of that time.

Trzebiński states that the absurd is a crucial moment in the development of medicine. This is primarily due to the pressure to find a cure or a therapeutic agent even against theoretical justification: 'This absurdity, however, is usually not a true absurdity but only seems to be one. Therefore, it is not a logical error but a crucial paradox in relation to the major opinions at a given time ${ }^{35}$ - those opinions which, by the obviousness of their acceptance in the medical community, became theoretical dogmas. Trzebiński's view is here related to that of Ludwik Fleck, who claimed that in medical cognition come into question

many elusive, from a logical point of view, imponderables that allow us to predict the course of issues and ideas that determine the development of a given field of thought and create the proper style of the epoch. ${ }^{36}$

Trzebiński also assumed that the imagination might play a more significant role when there are fewer theoretical justifications and the opposition between the dominant theoretical views (dogmas) and attempts to falsify them (absurdity) is a source of rationality, indicative of the discontinuous character of medical knowledge. For Fleck, however, all the views prevailing in the medical community are a consequence of having to think in a way that was fashionable at the time. ${ }^{37}$ Different explanations or therapeutic indications are the results of changing the way of thinking, mood, and assessment. Zygmunt Kramsztyk expressed this epistemological intuition:

A man does not look with his new, unprejudiced and new-born eyes but perceives with a mind full of information, theories, and prejudices, and thus sees the world in the colors of these information, theories, and prejudices. ${ }^{38}$

Therefore, absurdity is not only a proper feature of medicine in its historical - often prescientific - face, and Trzebiński's concept is not just an epistemology of unscientific elements of medical cognition. Today, we can also observe the resistance to questioning the views set and shared by doctors. The etiology of gastric ulcers is a good example. Dominant beliefs so far (theoretical and therapeutic dogma) have stated that the cause of peptic ulcer disease is excessively secreted gastric acid:

1. Peptic ulcer disease comes from stomach acidity.

2. Gastric acidity can be neutralized with antacids.

3. The peptic ulcer disease is treated with antacids. 
The concept of acidity originated from humoral medicine has been questioned in the premises of a clinical experiment discovering that the cause of ulceration is helicobacter pylori bacteria. This explanation, as well as the therapeutic indication, was also considered absurd. The rejection of Barry Marshall's and Robin Warren's (later Nobel Prize Winners) abstract sent to the Gastroenterological Conference in Australia is a good example. The scientific committee of the conference answered as follows: 'Dear Dr. Marshall, we are very sorry that we could not accept your abstract. This year there were so many submissions that we had 67 applications and we can only accept $64^{\prime} .{ }^{39}$ The acidity dogma did not give way to the bacteriological and infectious concept, despite attempts to challenge it since 1875, even when penicillin ulcer treatment was undertaken (in 1951). Marshall's and Warren's concept was considered absurd, and, according to Fleck, it did not conform to the dominant style of thinking of the epoch. Perhaps it was rejected according to the facetious principle denounced by Trzebiński: 'I may be wrong, but at least I'm in good company'. ${ }^{40}$ The difficulty of the new etiology of gastric ulcers proposed by Warren and Marshall lies in the fact that it comes from the already existing model of explanation.

\section{Rationality in medicine}

Cognitive absurdity appears when the established explanations of the causes of a given disease or the methods of treatment are questioned, but, at the same time, these explanations are rejected by the dominant representatives of medicine. Therefore, absurdity is a special moment of medical rationality that produces medical knowledge emerging from a tension between medical practice and medical theories. This tension may be described as follows: theoretically justified treatment may not produce the expected results, while a therapeutic method that is unsupported by theoretical considerations is effective. This tension is an effect of a discrepancy between theory and practice. Ludwig Fleck concludes similarly: 'Although impossible in theory, it does occur in practice'. ${ }^{41}$ This is possible because the rationality of medicine based on existing concepts of disease does not always lead to capturing the real relationship between phenomena: 'One can act erratically and still rationally'. ${ }^{42}$

However, if a medical concept (which is a dogma) persists against the results of a clinical experiment, questioning it becomes absurd. If it still persists, it turns into a superstition that is openly contradictory to existing medical claims or therapeutic guidelines. Finally, absurdity - as a denial of current knowledge or medical practice - supported by clinical experiments, develops rational knowledge (knowledge of the causes) that benefits the patient whose treatment is based on this knowledge. The justification for symptomatic treatment is finally understood as rational knowledge.

39 B. Marshall, an interview, Academy of Achievement, 23.05.1998, online publication: www.achievement.org/ autodoc/printmember/mar1int-1 [accessed 20.11.2018].

40 S. Trzebiński, Myśl lekarska w archiwum Wileńskiego Towarzystwa Lekarskiego według wykładu wygłoszonego na obchodzie 120-to letniej rocznicy Wileńskiego Towarzystwa Lekarskiego dnia 13 grudnia 1925 r., "Pamiętnik Wileńskiego Towarzystwa Lekarskiego" vol. 2, 1926, no 1, p. 20.

41 L. Fleck, Genesis and Development of Scientific Fact, p. 59.

42 Z. Kramsztyk, Racyonalne leczenie, [in:] Szkice z zakresu medycyny, ed. by Z. Kramsztyk, Warszawa 1899, p. 192. 
Trzebiński notes that, in his day, many claims regarded as superstitions were indicators of knowledge or medical practice in the past. Above all, however, 'superstition is constituted due to the accidental generalization of isolated facts' ${ }^{\prime 43}$, and also as a result of defending the dogma, although it can become a conjecture of relative rationality thanks to scientific achievements. The primary source of superstition lies in observational errors, experimental errors, and the hasty interpretation of statistical data. Szumowski recalls here David Hume's critique of causal relationship. The number of 'life factors' is infinite in logical reasoning. The history of medicine gives us many examples of hasty generalizations of recognizing one as the cause of the other. Verified by successive generations of philosophers, these generalizations are criticized and often refused: 'Too much haste in diagnosing a causal relationship where observation gives only a sequence in time is a chronic shortage of the so-called common sense' ${ }^{44}$ The complexity of the subject in medical observation and the research dealing with the human body, and the psychological predispositions of clinicians and patients, may encourage inappropriate generalizations in medical conclusions. Only an experiment as a deliberate act undertaken to test a hypothesis aims to establish a causal relationship between phenomena. ${ }^{45}$

Trzebiński grades the formal requirements in the proper medical theory. He distinguishes logic, rationality, and rationalism. Logic is understood as the correctness of reasoning, regardless of the validity of its content (syllogism). Rationality requires the correctness of reasoning and the rightness of the spoken judgment (compliance of judgment and observed facts). The rightness of judgment very often depends on the epoch and the environment. Finally, rationalism would be here a historically defined trend of thought. ${ }^{46}$ According to Trzebiński, rationality in medicine is, therefore, 'not only the correctness of reasoning, but also the rightness of judgment; but this legitimacy may be relative depending on the time and the environment' ${ }^{47}$ Due to the tension between medical practice and medical theories, rationality is a broader category than the authority of medicine because it presupposes a healing efficacy that is still not theoretically justified, i.e., without scientific support yet. The measure of this rationality is, first of all, the diagnosis of illnesses and the benefits brought to the patient. Finally - in this sense - the measure of medical treatment's rationality is the effective prevention of diseases and their effective treatment.

Rationality assumes the logic of transforming the results of a medical observation at the patient's bed into a medical indication, which requires confirmation or rejection in a medical experiment. Verification of the correctness of the derived medical indication is made by comparing the practical results obtained by using this method with the results obtained through other methods. The application of the experiment's results in clinical practice is aimed at achieving therapeutic efficacy or demonstrating the ineffectiveness of the current treatment method:

45 S. Trzebiński, Obserwacja, eksperyment i statystyka w logice medycyny Władysława Biegańskiego, "Archiwum Historii i Filozofii Medycyny" vol. 6, 1927, no 2, p. 176.

46 S. Trzebiński, Racjonalność i racjonalizm w medycynie, p. 92-93.

47 Ibid., p. 93. 
The doctor who knows the 'latest requirements' of medicine and acts according to them heals rationally; the one who does not know them and persists in using outdated methods is rather an empiricist. Empiricists - 'scholar' doctors - have a common tendency to confuse rationality with rationalism. The teaching program contributes to this at every stage, and the essential role of irrational factors is systematically neglected. ${ }^{48}$

Jędrzej Śniadecki's (1768-1838) methodological indications are helpful here. In his Theory of Organic Beings (1804) he wrote:

In order to make the division of any science and to assess its value, it is necessary to recognize the value and certainty of the origins upon which it is based. If it turns out that they are not evident and strong enough, the entire structure will collapse and will lose its pace. If, however, the foundations are certain, one should take the lessons learned from them and use this knowledge, considering whether the builder of this skill has not moved too far away from experience and pure logic' ${ }^{49}$

This view is certainly in line with Zygmunt Kramsztyk and his reflections on the clinical fact: 'Therefore, no clinical fact is as stable and as reliable as a simple physical fact. The experiment can only simplify the living nature to some extent. (...) However, if the hypothesis is to satisfy the critical mind, if it is to be somewhat more durable and closer to the essential truth, then it should be based on simple facts or, at least, on certain and constant facts. ${ }^{50}$

\section{Conclusions}

The Polish school of philosophy of medicine was, in its time, a global phenomenon. Ilana Löwy describes the atmosphere of this circle:

This school was an utterly unique phenomenon in the history of medicine, primarily because it existed as a specific school. This is probably the only case - before the bioethics and philosophy of medicine developed in the Anglo-Saxon countries in the sixties and seventies of the twentieth century - of the existence of a longstanding tradition of taking up philosophical and medical issues. ${ }^{51}$

Philosophical reflection was present in medicine from antiquity to the Enlightenment, but the strong development of empirical sciences in the nineteenth century separated it from strict medical knowledge. Poles were probably the first who reflected critically on the practice of medical sciences and worked out a modern theory of medical theory of cognition. This is the appropriate context for Trzebiński's philosophical work.

48 Ibid., p. 100-101

49 J. Śniadecki, Teorya jestestw organicznych. Wydanie Jubileuszowe poświęcone Wileńskiemu Towarzystwu Lekarskiemu, Poznań 1905, p. 112.

50 Z. Kramsztyk, Fakt kliniczny, p. 31-33.

51 I. Löwy, Polska szkoła filozofii medycyny. Od Tytusa Chałubińskiego do Ludwika Flecka, Wrocław - Warszawa Kraków 1992, p. 3. 
His epistemological concept still requires a more detailed reconstruction and the will to apply it to the analysis of contemporary medical knowledge and practice. It has to be noted that Trzebiński was probably the first to express the basis of rationality in medicine so clearly. Today this rationality is the foundation of the 'Evidence-Based Medicine' system, which assumes the skillful use of clinically confirmed, reliable scientific data and guarantees the effectiveness of therapeutic measures, including the scientific evaluation of patient's benefits from therapy. The individualization of the therapeutic process was also Trzebiński's concept. He wrote:

The first concern of the doctor who wants to act rationally in the complete sense of the word should be - apart from a thorough examination of the patient - establishing a mental connection with him. This relationship is based on the patient's belief that the doctor not only can but also wants to help him with all his might. When there is no such faith, the treatment, even if relatively rationally designed, will be consciously and unconsciously opposed by the patient or his environment, which will either hinder or interfere with its effectiveness. ${ }^{52}$

Kramsztyk also embraced this understanding of the rationality in medicine focused on the patient:

the necessary consequence of a perfect rational procedure is its infallibility. The doctor must calculate the extent of his help for the patient most accurately, and the result of this calculation must be fulfilled. ${ }^{53}$

The concept of absurdity in medicine, which is similar to Fleck's style of thinking (which also requires further studies), is still a valid tool for analyzing the development of medical sciences and practices. Trzebiński's cognitive relativism reveals the dynamics of the development of medicine. He wrote:

In the history of medicine, we deal relatively often with allegations of absurdity. They usually occur in the process of more important issues of change. Taking a different starting point, they result either from theoretical reasoning or from the medical experience that seems to prove the harmfulness of treatment according to opponent's rules. ${ }^{54}$

He also stressed that medical knowledge and practice - at any time - is not a carrier of absolute truth:

I am trying to get acquainted with these tiny shells thrown onto our shore by the waves of the great ocean of transcendentalism, and I am convinced that in this world we have the right not to believe a priori, but on the other hand, we should not reject any knowledge a limine. ${ }^{55}$

52 S. Trzebiński, Racjonalność $i$ racjonalizm w medycynie, p. 102-103.

53 Z. Kramsztyk, Racyonalne leczenie, p. 191.

54 S. Trzebiński, Absurdalność w medycynie, p. 89.

55 Idem, Transcendentalizm a wiedza przyrodnicza i lekarska, p. 158. 


\section{Bibliography}

\section{Sources}

Bilikiewicz T., IV Zjazd polskich historyków i filozofów medycyny, "Archiwum Historii i Filozofii Medycyny" vol. 9, 1929, no 1, p. 137-148.

Kramsztyk Z., Fakt kliniczny, "Krytyka lekarska" 1898, no 2, p. 29-38.

Kramsztyk Z., Racyonalne leczenie, [in:] Szkice z zakresu medycyny, ed. by Z. Kramsztyk, Warszawa 1899, p. 189-196.

Podgórzanin B. (Łętowski L.), Miscellanea, vol. 1, Kraków 1866.

Szumowski W., Filozofia medycyny, Kęty 2007.

Szumowski W., O związku przyczynowym w medycynie, "Archiwum Historii i Filozofii Medycyny" vol. 2, 1925, no 2, p. 229-240.

Śniadecki J., Teorya jestestw organicznych. Wydanie Jubileuszowe poświęcone Wileńskiemu Towarzystwu Lekarskiemu, Poznań 1905.

Trzebiński S., Racjonalność i racjonalizm w medycynie, "Archiwum Historii i Filozofii Medycyny" vol. 2, 1925, no 1, p. 91-103.

Trzebiński S., Blane, Oesterlen i Biegański- 3 Logiki medycyny, "Nowiny Lekarskie" vol. 38, 1926, no 23, p. 886-892.

Trzebiński S., Przesąd w medycynie, "Archiwum Historii i Filozofii Medycyny" vol. 4, 1926, no 1, p. 94-105.

Trzebiński S., Myśl lekarska w archiwum Wileńskiego Towarzystwa Lekarskiego według wykładu wygłoszonego na obchodzie 120-to letniej rocznicy Wileńskiego Towarzystwa Lekarskiego dnia 13 grudnia 1925 r., "Pamiętnik Wileńskiego Towarzystwa Lekarskiego" vol. 2, 1926, no 1, p. 19-28.

Trzebiński S., Absurdalność w medycynie, "Archiwum Historii i Filozofii Medycyny" vol. 7, 1927, no 1, p. 72-89.

Trzebiński S., Obserwacja, eksperyment i statystyka w logice medycyny Władysława Biegańskiego, "Archiwum Historii i Filozofii Medycyny" vol. 6, 1927, no 2, p. 173-194.

Trzebiński S., Transcendentalizm a wiedza przyrodnicza i lekarska, "Archiwum Historii i Filozofii Medycyny" vol. 15, 1935, no 2, p. 139-158.

Trzebiński S., Wydział lekarski Uniwersytetu Stefana Batorego w latach 1919-1929, Wilno 1931.

Trzebiński S., V Zjazd Polskich Historyków i Filozofów Medycyny w r. 1929, "Archiwum Historii i Filozofii Medycyny" vol. 11, 1931, no 1-2, p. 252-267.

\section{Critical literature}

Barański J., Stanisław Trzebiński, [in:] Polska szkoła filozofii medycyny. Przedstawiciele i wybrane teksty źródłowe, ed. by Musielak M., Zamojski J., Poznań 2010, pp. 129146.

Fleck L., Genesis and Development of Scientific Fact, Chicago - London 2006.

Fleck L., Psychosocjologia poznania naukowego, Lublin 1986.

Gryglewski R.W., Filozofia medycyny Ferdynanda Karola Dworzaczka, "Archiwum Historii i Filozofii Medycyny" vol. 69, 2006, no 1-2, p. 41-46.

Gryglewski R.W., Czy medycyna jest sztuką czy nauką? - rozważania w świetle polskiej szkoły filozofii medycyny i poglądów innych lekarzy europejskich czasów przełomu 
XIX w. do wybuchu II wojny światowej, "Medycyna Nowożytna" vol. 13, 2006, no $1-2$, p. 7-24.

Gryglewski R.W., O filozoficznym ujęciu medycyny przez Stanisława Trzebińskiego, "Forum Bibliotek Medycznych" 2015, no 2, p. 249-260.

Januszkiewicz A., Śp. Prof. Dr. Stanisław Trzebiński. Na podstawie danych biograficznych i własnych wspomnień, "Pamiętnik Wileńskiego Towarzystwa Lekarskiego" vol. 6, 1930, no 4-5, p. I-XXII.

Jastrzębowski Z., Srogosz T., Polska szkoła filozofii medycyny a marksizm, “Medycyna Nowożytna" vol. 1, 1994, no 2, p. 61-68.

Kuhn T., The Structure of Scientific Revolutions, online edition, projektintegracija.pravo. hr/_download/repository/Kuhn_Structure_of_Scientific_Revolutions.pdf [accessed 14.11.2018].

Löwy I., The Polish School of Philosophy of Medicine, New York 1990, DOI 10.1007/97894-009-2135-1.

Löwy I., "Medical Critique" ["Krytyka Lekarska"]: A Journal of Medicine and Philosophy 1897-1907, "The Journal of Medicine \& Philosophy" vol. 15, 1990, issue 6, p. 653-674, DOI 10.1093/jmp/15.6.653.

Löwy I., Polska szkoła filozofii medycyny. Od Tytusa Chałubińskiego do Ludwika Flecka, Wrocław - Warszawa - Kraków 1992.

Matlakowski W., Fabian A., Dr Filozofii Julian Ochorowicz i nauka. Przyczynek do historii cywilizacji i u nas, "Gazeta Lekarska" vol. 8, 1888, no 23, p. 477-509.

Marshall B., Interview, Academy of Achievement, 23.05.1998, online publication: achievement.org/autodoc/printmember/mar1int-1 [accessed 20.11.2018].

Płonka-Syroka B., An Overview of the Polish School of Medical Philosophy from the 19th Century to Today, "Journal of Pharmacy and Pharmacology" 2014, no 2, p. 509-526.

Wrzosek A., Życie $i$ działalność naukowa Stanisława Trzebińskiego, "Archiwum Historii i Filozofii Medycyny" vol. 14, 1934, no 1-2, p. 217-251.

Zamojski J., Dlaczego wciąż warto badać polską myśl filozoficzno-lekarską?, [in:] Polska szkoła filozofii medycyny, Poznań 2010, ed. by M. Musielak, J. Zamojski, p. 21-28.

Zamojski J., Petrů M., Musielak M., Vladykova L., Polske filosofické myšlenía medicína, Ostrava - Košice 2012.

Prof. (dr hab.) Jarosław Barański, assistant professor, head of the Department of Humanities in Medicine at the Wroclaw Medical University. He works on the philosophy and sociology of the body, aesthetics, and medical ethics. He is the author of books on the philosophy of medicine and aesthetics, and a co-editor of textbooks on patient communication and medical sociology.

Dr Wojciech Mackiewicz, research assistant in the Department of Humanities on Medicine at the Wroclaw Medical University. He works on philosophy of the body, medical metaphors, philosophy, and sociology of medicine.

e-mail: wojciech.mackiewicz@umed.wroc.pl

Article submitted on 20 February 2020

Article accepted on 15 October 2020 
Absurd w medycynie. Filozofia medycyny Stanisława Trzebińskiego

Stanisław Trzebiński (1861-1930), profesor Uniwersytetu Stefana Batorego w Wilnie, był jednym z najwybitniejszych przedstawicieli polskiej szkoły filozofii medycyny przed drugą wojną światową. Podejmował badania z dziedziny neurologii, filozofii medycyny i literatury.

Artykuł omawia koncepcje filozoficzne Trzebińskiego, w szczególności jego wezwanie do racjonalności w filozofii i koncepsję absurfu w medycynie jako warunku wstępnego rozwoju wiedzy i praktyki medycznej. Dzisiaj ta metoda jest fundamentalna dla medycyny opartej na faktach (Evidence-Based Medicine) oraz potwierdza kulturową i naukową formę poznania. 